КРАТКИЕ СООБЩЕНИЯ

UDC 548.73:541.49

\title{
CRYSTAL STRUCTURE AND INSULIN-LIKE ACTIVITY OF A VANADIUM COMPLEX DERIVED FROM $N^{\prime}$-(3,5-DICHLORO-2-HYDROXYBENZYLIDENE)-2-METHYLBENZOHYDRAZIDE
}

\author{
S. $\mathrm{H} \mathrm{a} \mathrm{n}{ }^{1}, \mathrm{Y} . \mathrm{W}$ a n $\mathbf{g}^{2}$ \\ ${ }^{1}$ College of Chemistry and Chemical Engineering, Qiqihar University, Qiqihar, P. R. China \\ E-mail: hanzhq2088@163.com \\ ${ }^{2}$ Qiqihar Environmental Monitoring Central Station, Qiqihar, P. R. China
}

Received March, 20, 2014

\begin{abstract}
Vanadium complexes have been proved to possess an interesting insulin-like activity. The reaction of $\mathrm{VO}(\mathrm{acac})_{2}$ with $N^{\prime}$-(3,5-dichloro-2-hydroxybenzylidene)-2-methylbenzohydrazide $\left(\mathrm{H}_{2} \mathrm{~L}\right)$ in methanol affords a new mononuclear vanadium $(\mathrm{V})$ complex [VOL(OMe) $\left.(\mathrm{MeOH})\right]$. The structure of the complex is characterized by physicochemical methods and single crystal $\mathrm{X}$-ray diffraction. The complex crystallizes as the monoclinic space group $P 2_{1} / n$, with unit cell parameters $\quad a=7.830(2) \AA, \quad b=23.225(3) \AA, \quad c=10.635(2) \AA, \quad \beta=101.947(2)^{\circ}, \quad V=$ $=1892.1(6) \AA^{3}, Z=4, R_{1}=0.0404, w R_{2}=0.0953, S=1.037$. The X-ray analysis indicates that the $\mathrm{V}$ atom in the complex is in the octahedral coordination. The insulin-like activity of the complex is studied.
\end{abstract}

DOI: $10.15372 /$ JSC20150627

K e y w o r d s: hydrazone ligand, vanadium complex, crystal structure, insulin-like activity.

Transition metal complexes with various ligands have received much attention because they exhibit interesting biological activities. The increasing interest in the coordination chemistry of vanadium arises from its well-established chemical and biological functions [ $1-5]$. Vanadium is recognized as an essential trace element for different organisms [6]. The element is present in vanadiumcontaining enzymes such as nitrogenase and haloperoxidases [7]. Due to the structural similarity between vanadates and phosphates and the ability to be transported into cells through the anion channel of plasma membranes $[8,9]$, many vanadium compounds have been shown to increase glucose transport into cells and oxidation via glycolysis [10,11]. Oxovanadium(IV) sulphate has been demonstrated to possess the oral insulin-like activity similar to that of vanadates but with lowered toxicity [12 ]. Oxovanadium(IV) salts, however, are known to be poorly absorbed and are less bio-available compared to vanadates $[13,14]$. Therefore, a number of low molecular weight vanadium complexes have been prepared and studied on their insulin-like activity in an attempt to improve the vanadium bioavailability [15-17]. In general, these complexes exhibit the insulin-like activity and are effective at lower doses with demonstrable lower toxicities than vanadium salts [18 ]. In addition, such vanadium complexes normalized glucose and lipid values without an increase in insulin levels and improved glucose tolerance. Considering hydrazone ligands to be bioactive species [19], in the present paper, we report the synthesis, characterization, and insulin-like activity of a new vanadium complex [VOL $(\mathrm{OMe})(\mathrm{MeOH})]$, where $\mathrm{L}$ is the dianionic form of the hydrazone ligand $N^{\prime}$-(3,5-dichloro-2hydroxybenzylidene)-2-methylbenzohydrazide $\left(\mathrm{H}_{2} \mathrm{~L}\right)$.

Experimental. General methods and materials. $\mathrm{VO}(\mathrm{acac})_{2}, 3,5$-dichlorosalicylaldehyde, and 2-methylbenzohydrazide were purchased (Lancaster) and used as received. All other reagents were of

(C) Han S., Wang Y., 2015 
analytical grade. Elemental analyses of C, H, and N were carried out on a 2400 Series-II CHN analyzer. FT-IR spectra were obtained on a Jasco FT/IR-4000 spectrometer with samples prepared as $\mathrm{KBr}$ pellets. Molar conductance was measured with a Shanghai DDS-11A conductometer. Thermal analysis of the complex was carried out on a Perkin Elmer TGA-4000 thermo balance. The in vitro insulinmimic activity was determined according to the literature method [ 17].

Synthesis of the complex. 3,5-Dichloro-2-hydroxybenzaldehyde $(0.19 \mathrm{~g}, 1.0 \mathrm{mmol})$ and 2-methylbenzohydrazide $(0.15 \mathrm{~g}, 1.0 \mathrm{mmol})$ were dissolved and mixed in methanol $(20 \mathrm{ml})$. The mixture was stirred at room temperature for $10 \mathrm{~min}$ to give a colorless solution. To the solution a methanol solution $(20 \mathrm{ml})$ containing $\mathrm{VO}(\mathrm{acac})_{2}(0.26 \mathrm{~g}, 1.0 \mathrm{mmol})$ was added dropwise. The color immediately changed to brown. The brown mixture was stirred at room temperature for $30 \mathrm{~min}$ and filtered. The filtrate was kept at ambient temperature. Single crystals of the complex, suitable for X-ray diffraction, were grown from the filtrate upon slow evaporation within a few days. The crystals were isolated by filtration, washed with methanol, and dried in air. Yield $67 \%$.

Characteristic IR data $\left(\mathrm{cm}^{-1}\right): 3430 \mathrm{w}, 1610 \mathrm{~s}, 1495 \mathrm{~s}, 1433 \mathrm{~m}, 1386 \mathrm{~m}, 1350 \mathrm{~m}, 1281 \mathrm{w}, 1037 \mathrm{~s}$, 963m, 910w, 745w, 636m, 587w, 486w, 431w. Anal. Calcd for $\mathrm{C}_{38} \mathrm{H}_{44} \mathrm{Cu}_{2} \mathrm{~N}_{4} \mathrm{O}_{10}(\%)$ : C 54.08, H 5.26, N 6.64; found (\%): C 54.23, H 5.33, N 6.54.

X-ray crystallography. Single crystal X-ray diffraction data for the complex were collected on a Bruker Smart $1000 \mathrm{CCD}$ diffractometer at $298(2) \mathrm{K}$ with $\operatorname{Mo} K_{\alpha}$ radiation $(\lambda=0.71073 \AA)$ by the $\omega$ scan mode. The SAINT program [20] was used for the integration of the diffraction profiles. The structure was solved by direct methods using the SHELXS program of the SHELXTL package and

T a b l e 1

\section{Crystallographic Information for the Complex}

\begin{tabular}{|c|c|}
\hline Formula & $\mathrm{C}_{17} \mathrm{H}_{17} \mathrm{Cl}_{2} \mathrm{~N}_{2} \mathrm{O}_{5} \mathrm{~V}$ \\
\hline Formula weight & 451.2 \\
\hline Crystal shape / color & Block / brown \\
\hline$T, \mathrm{~K}$ & $298(2)$ \\
\hline Crystal dimensions, $\mathrm{mm}$ & $0.32 \times 0.32 \times 0.30$ \\
\hline Crystal system & Monoclinic \\
\hline Space group & $P 22_{1} / n$ \\
\hline$a, b, c, \AA$ & $7.830(2), 23.225(3), 10.635(2)$ \\
\hline$\beta$, deg. & $101.947(2)$ \\
\hline$V, \AA^{3}$ & $1892.1(6)$ \\
\hline$Z$ & 4 \\
\hline$D_{\text {calc }}, \mathrm{g} / \mathrm{cm}^{3}$ & 1.584 \\
\hline$\mu\left(\operatorname{Mo} K_{\alpha}\right), \mathrm{mm}^{-1}$ & 0.838 \\
\hline$F(000)$ & 920 \\
\hline Measured / Unique / Observed reflections $(I \geq 2 \sigma(I))$ & 15848 / $4046 / 3428$ \\
\hline Parameters & 250 \\
\hline Restraints & 1 \\
\hline Min. and max. transmission & 0.7753 and 0.7871 \\
\hline Goodness of fit on $F^{2}$ & 1.037 \\
\hline$R_{1}, w R_{2}[I \geq 2 \sigma(I)]^{a}$ & $0.0404,0.0953$ \\
\hline$R_{1}, w R_{2}(\text { all data })^{a}$ & $0.0494,0.1003$ \\
\hline Largest different peak and hole, e $/ \AA^{3}$ & $0.325,-0.301$ \\
\hline
\end{tabular}


Selected Bond Lengths $(\AA)$ and Angles (deg.) for the Complex with Estimated Standard Deviations (e.s.d.s) in Parentheses

\begin{tabular}{c|l|l|r||r|r}
\hline \multicolumn{2}{c|}{ Bond distances } & \multicolumn{5}{c}{ Bond angles } \\
$\mathrm{V}(1)-\mathrm{O}(1)$ & $1.854(2)$ & $\mathrm{O}(3)-\mathrm{V}(1)-\mathrm{O}(4)$ & $102.93(9)$ & $\mathrm{O}(3)-\mathrm{V}(1)-\mathrm{O}(1)$ & $99.60(9)$ \\
$\mathrm{V}(1)-\mathrm{O}(3)$ & $1.580(2)$ & $\mathrm{O}(4)-\mathrm{V}(1)-\mathrm{O}(1)$ & $104.42(8)$ & $\mathrm{O}(3)-\mathrm{V}(1)-\mathrm{O}(5)$ & $96.12(9)$ \\
$\mathrm{V}(1)-\mathrm{O}(5)$ & $1.946(2)$ & $\mathrm{O}(1)-\mathrm{V}(1)-\mathrm{O}(5)$ & $154.34(7)$ & $\mathrm{O}(3)-\mathrm{V}(1)-\mathrm{N}(1)$ & $97.56(8)$ \\
$\mathrm{V}(1)-\mathrm{O}(2)$ & $2.367(2)$ & $\mathrm{O}(4)-\mathrm{V}(1)-\mathrm{N}(1)$ & $155.97(8)$ & $\mathrm{O}(1)-\mathrm{V}(1)-\mathrm{N}(1)$ & $84.15(7)$ \\
$\mathrm{V}(1)-\mathrm{O}(4)$ & $1.750(2)$ & $\mathrm{O}(5)-\mathrm{V}(1)-\mathrm{N}(1)$ & $73.74(7)$ & $\mathrm{O}(3)-\mathrm{V}(1)-\mathrm{O}(2)$ & $174.39(8)$ \\
$\mathrm{V}(1)-\mathrm{N}(1)$ & $2.127(2)$ & $\mathrm{O}(4)-\mathrm{V}(1)-\mathrm{O}(2)$ & $81.81(7)$ & $\mathrm{O}(1)-\mathrm{V}(1)-\mathrm{O}(2)$ & $81.93(8)$ \\
& & $\mathrm{O}(5)-\mathrm{V}(1)-\mathrm{O}(2)$ & $80.63(7)$ & $\mathrm{N}(1)-\mathrm{V}(1)-\mathrm{O}(2)$ & $77.18(6)$
\end{tabular}

refined by full-matrix least-squares methods using SHELXL (semi-empirical absorption corrections were applied using the SADABS program) [21,22]. The positions of the non-hydrogen atoms were located in difference Fourier maps and least-squares refinement cycles, and finally refined anisotropically. The methanol hydrogen atom was located from the electron density map and refined isotropically, with $\mathrm{O}-\mathrm{H}$ distance being restrained to $0.85(1) \AA$. The remaining hydrogen atoms of the complexes were placed theoretically onto the specific atoms and refined isotropically as riding atoms. Crystallographic data and experimental details for structural analyses are summarized in Table 1 . Selected bond lengths and angles for the complex are listed in Table 2.

Supplementary material for the structure has been deposited with the Cambridge Crystallographic Data Centre (No. 858859; deposit@ccdc.cam.ac.uk or http://www.ccdc.cam.ac.uk).

Results and discussion. Synthesis and characterization. The hydrazone ligand was prepared by the reaction of 3,5-dichloro-2-hydroxybenzaldehyde and 2-methylbenzohydrazide in methanol. The ligand was not isolated and purified, and was used to prepare the vanadium complex with $\mathrm{VO}(\mathrm{acac})_{2}$. The elemental analysis of the complex is in accordance with the molecular structure proposed by the $\mathrm{X}$-ray analysis. The complex shows typical $\mathrm{C}=\mathrm{N}$ absorption at $1610 \mathrm{~cm}^{-1}$ and typical $\mathrm{V}=\mathrm{O}$ absorption at $963 \mathrm{~cm}^{-1}$ [23 ]. The bands due to $v(\mathrm{~V}-\mathrm{N})$ and $v(\mathrm{~V}-\mathrm{O})$ are observed at $475-550 \mathrm{~cm}^{-1}$ and $410-$ $460 \mathrm{~cm}^{-1}$ respectively. The complex is stable in air at room temperature and did not decompose on heating up to $250{ }^{\circ} \mathrm{C}$. The molar conductivity of the complex measured in acetonitrile at a concentration of $10^{-3} \mathrm{M}$ is $15 \Omega^{-1} \cdot \mathrm{cm}^{2} \cdot \mathrm{mol}^{-1}$, indicating the non-electrolytic nature of the complex in solution [24 ].

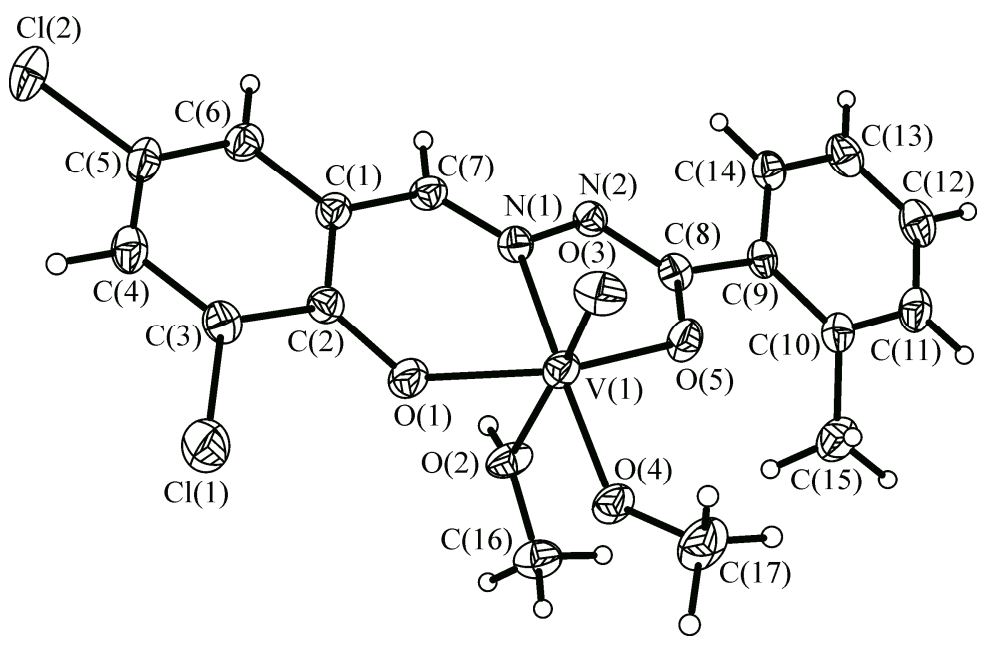

Fig. 1. A perspective view of the molecular structure of the complex. Thermal ellipsoids are drawn at the $30 \%$ probability level 


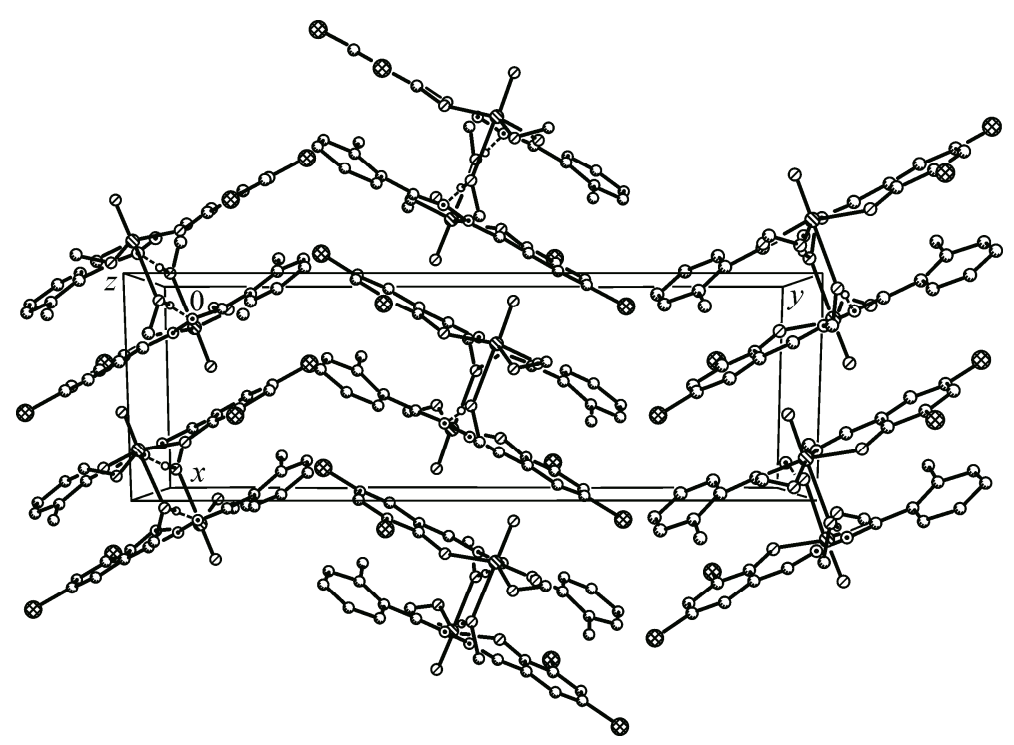

Fig. 2. A perspective view of the dimeric structure of the complex

Structure description of the complex. The molecular structure of the complex is shown in Fig. 1. The $\mathrm{V}$ atom is in the octahedral coordination and is coordinated by one hydrazone ligand, one oxo oxygen atom, one deprotonated methanol molecule, and one normal methanol molecule. The hydrazone ligand coordinates to the $\mathrm{V}$ atom via the phenolate oxygen, one imino nitrogen, and one enalate oxygen atoms. As expected, the normal methanol ligand is situated at the opposite position of the oxo oxygen atom. Thus, the $\mathrm{V}(1)-\mathrm{O}(2)$ bond is much longer than $\mathrm{V}(1)-\mathrm{O}(4)$. The $\mathrm{V}$ atom is situated by 0.308(1) $\AA$ from the least-squares plane defined by the equatorial donor atoms (O1, N1, O4, and O5). The dihedral angle between the two benzene rings is $8.7(3)^{\circ}$.

In the crystal packing (Fig. 2), two adjacent molecules are linked via the $\mathrm{O}(2)-\mathrm{H}(2) \cdots \mathrm{N}(2)$ hydrogen bond $\left[\mathrm{O}(2)-\mathrm{H}(2)=0.85(1) \AA, \mathrm{H}(2) \cdots \mathrm{N}(2)^{i}=2.01(1) \AA, \mathrm{O}(2) \cdots \mathrm{N}(2)^{i}=2.854(2) \AA, \mathrm{O}(2)-\right.$ $\mathrm{H}(2) \cdots \mathrm{N}(2)^{i}=174(3)^{\circ}$; symmetry code for $\left.i:-x,-y, 2-z\right]$.

Thermal analysis. TG-DTA curves (Fig. 3) show the mass losses corresponding to the normal methanol ligand at $80-120^{\circ} \mathrm{C}$, and the deprotonated methanol ligand at $130-250{ }^{\circ} \mathrm{C}$. The hydrazone ligand of the complex decomposes at $250-480^{\circ} \mathrm{C}$ with a DTA peak at $477{ }^{\circ} \mathrm{C}$. The total mass loss $(80.7 \%)$ corresponds to the loss of the ligands and the formation of $\mathrm{V}_{2} \mathrm{O}_{5}$ as the final product.

Insulin-like activity. The presence of the complex in the incubation medium stimulated glucose uptake, with a 2-DOG uptake value of $0.67 \mathrm{nmol} / 3 \mathrm{~min}$. However, both insulin (IN) and [VO(acac) $)_{2}$ ]

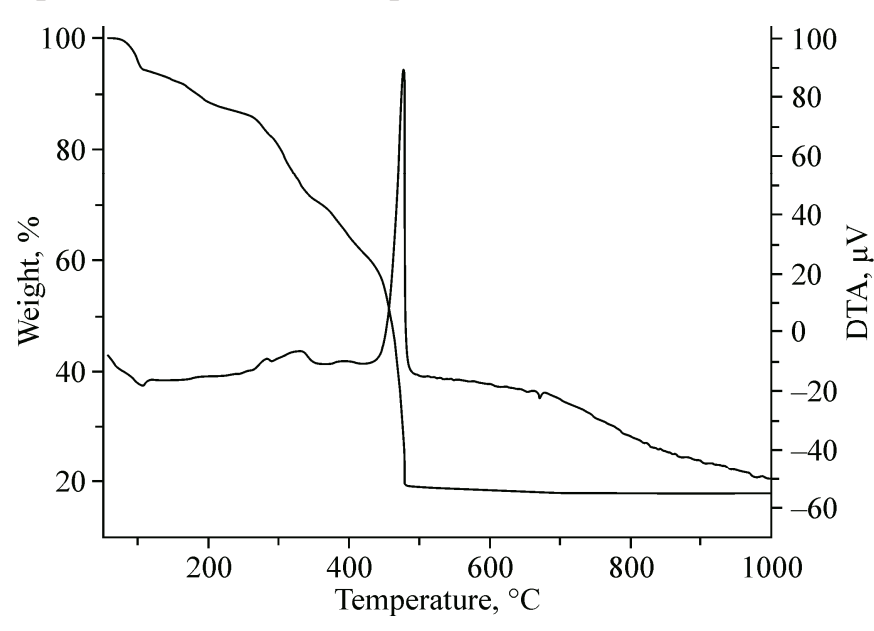
are more effective than the present complex in enhancing glucose uptake by adipocytes, with 2-DOG uptake values being $1.70 \mathrm{nmol} / 3 \mathrm{~min}$ and $1.51 \mathrm{nmol} / 3 \mathrm{~min}$ respectively. A further study indicated that the complex inhibited glycerol release by adipocytes in a similar way as that observed with insulin. The results in the present work are similar to those of vanadium complexes with thiosemicarbazone ligands reported by Beraldo and coworkers [17].

Fig. 3. TG-DTA curves of the complex 
This work was financially supported by the Program for Young Teachers Scientific Research in Qiqihar University (2012k-M05), and the Education Office of Heilongjiang Province (Project No. 12531757).

\section{REFERENCES}

1. Scior T., Guevara-Garcia J.A., Melendez F.J., Abdallah H.H., Do Q.T., Bernad P. // Drug Des., Dev. Ther. -2010. - 4. - P. $231-242$.

2. Rivadeneira J., Barrio D.A., Arrambide G., Gambino D., Bruzzone L., Etcheverry S.B. // J. Inorg. Biochem. -2009. - 103, N 4. - P. $633-642$.

3. Guilherme L.R., Massabni A.C., Cuin A., Oliveira L.A.A., Castellano E.E., Heinrich T.A., Costa-Neto C.M. // J. Coord. Chem. - 2009. - 62, N 10. - P. $1561-1571$.

4. Frank P., Carlson E.J., Carlson R.M.K., Hedman B., Hodgson K.O. // J. Inorg. Biochem. - 2008. - 102, N 4. - P. $809-823$.

5. Ashiq U., Ara R., Mahroof-Tahir M., Maqsood Z.T., Khan K.M., Khan S.N., Siddiqui H., Choudhary M.I. // Chem. Biodiversity. - 2008. - 5, N 1. - P. 82 - 92.

6. Mochizuki M., Kudo E., Kikuchi M., Takano T., Taniuchi Y., Kitamura T., Hondo R., Ueda F. // Biol. Trace Elem. Res. - 2011. - 142, N 1. - P. $117-126$.

7. Hu Y.L., Lee C.C., Ribbe M.W. // Dalton Trans. - 2012. - 41, N 4. - P. $1118-1127$.

8. Crans D.C., Schoeberl S., Gaidamauskas E., Baruah B., Roess D.A. // J. Biol. Inorg. Chem. - 2011. - 16, N 6. - P. $961-972$.

9. Li S.H., McNeill J.H. // Mol. Cell Biochem. - 2001. - 217, Nos. 1-2. - P. 121 - 129.

10. Hwang S.-L., Chang H.W. // Mol. Cell Biochem. - 2012. - 360, Nos. 1-2. - P. 401 - 409.

11. Sanna D., Micera G., Garribba E. // Inorg. Chem. - 2010. - 49, N 1. - P. $174-187$.

12. Delgado T.C., Tomaz A.I., Correia I., Pessoa J.C., Jones J.G., Geraldes C.F.G.C., Castro M.M.C.A. // J. Inorg. Biochem. - 2005. - 99, N 12. - P. 2328 - 2339.

13. Lu B., Ennis D., Lai R., Bogdanovic E., Nikolov R., Salamon L., Fantus C., Le-Tien H., Fantus I.G. // J. Biol. Chem. - 2001. - 276, N 38. - P. 35589 - 35598.

14. Cocco M.T., Onnis V., Ponticelli G., Meier B., Rehder D., Garribba E., Micera G. // J. Inorg. Biochem. -2007. - 101, N 1. - P. $19-29$.

15. Pillai S.L., Subramanian S.P., Kandaswamy M. // Eur. J. Med. Chem. - 2013. - 63, N 63. - P. $109-117$.

16. Crans D.C., Trujillo A.M., Pharazyn P.S., Cohen M.D. // Coord. Chem. Rev. - 2011. - 255, Nos 19-20. - P. $2178-2192$.

17. Mendes C., Botion L.M., Ferreira A.V.M., Castellano E.E., Beraldo H. // Inorg. Chim. Acta. - 2009. - 362, N 2. - P. $414-420$.

18. Nejo A.A., Kolawole G.A., Opoku A.R., Wolowska J., Obrien P. // Inorg. Chim. Acta. - 2009. - 362, N 11. - P. $3993-4001$.

19. Altintop M.D., Ozdemir A., Turan-Zitouni G., Ilgin S., Atlik O., Iscan G., Kaplancikli Z.A. // Eur. J. Med. Chem. - 2012. - 58, N 58. - P. $299-307$.

20. Bruker AXS, SAINT Software Reference Manual, Madison, Wisconsin, 1998.

21. Sheldrick G.M. SADABS, Siemens Area Detector Absorption Corrected Software, University of Göttingen, Germany, 1996.

22. Sheldrick G.M. // Acta Crystallogr. - 2008. - A64, N 1. - P. 112 - 122.

23. Sarkar A., Pal S. // Polyhedron. - 2006. - 25, N 7. - P. $1689-1694$.

24. Geary W.J. // Coord. Chem. Rev. - 1971. - 7, N 1. - P. 81 - 122. 